\title{
ESPAÇOS DAS MIGRAÇÕES TRANSNACIONAIS: PERFIL SOCIODEMOGRÁFICO DE IMIGRANTES DA ÁFRICA PARA O BRASIL NO SÉCULO XXI
}

\author{
Spaces of transnational migration: a sociodemographic profile of \\ African migrants in Brazil in the 21st century
}

\author{
Rosana Baeninger \\ Natália Belmonte Demétrio** \\ Jóice de Oliveira Santos Domeniconi***
}

\begin{abstract}
Resumo. Esse trabalho tem por objetivo construir um perfil sociodemográfico da imigração africana para o Brasil. Parte-se do aporte teórico das migrações transnacionais como recurso analítico que articula as transformações advindas da divisão internacional do trabalho aos processos que ocorrem dentro das fronteiras nacionais. Em termos metodológicos, são utilizados registros administrativos de diversas instituições brasileiras: Polícia Federal, Comitê Nacional para Refugiados e Relação Anual de Informações Sociais da Secretaria de Trabalho.

Palavras-chave: migração internacional; transnacionalismo; África; Brasil.

Abstract. This paper aims to build a sociodemographic profile of African immigration to Brazil. It builds on the theory of transnational migration that enables us to analyze transformations arising from the international division of labor as well as from processes that occur within national borders. Methodologically, administrative records of several Brazilian institutions are used: the Federal Police, the National Committee for Refugees and the Annual Report of Social Information of the Secretariat of Labor.
\end{abstract}

Keywords: international migration; transnationalism; Africa; Brazil.

\footnotetext{
Professora do Departamento de Sociologia e Demografia do Instituto de Filosofia e Ciências Humanas da Universidade Estadual de Campinas. Pesquisadora do Núcleo de Estudos de População Elza Berquó (Nepo/Unicamp). Campinas - SP, Brasil. E-mail: baeninger@nepo. unicamp.br. Orcid: 0000-0002-3817-2807.

** Pesquisadora colaboradora do Núcleo de Estudos de População Elza Berquó (Nepo/Unicamp). Bolsista de Pós-Doutorado Júnior (PDJ - CNPq) no Nepo/Unicamp. Campinas - SP, Brasil. E-mail: natalia@nepo.unicamp.br. Orcid: 0000-0003-0954-6993.

*** Pesquisadora do Observatório das Migrações em São Paulo. Doutoranda em Demografia no Instituto de Filosofia e Ciências Humanas da Universidade Estadual de Campinas. Campinas - SP, Brasil. E-mail: joicedomeniconi@nepo.unicamp.br. Orcid: 0000-0002-5606-448X.
} 


\section{Introdução: Africanos no Brasil no contexto das relações Sul-Sul}

As desigualdades estruturadas no âmbito da divisão internacional do trabalho ganham novos contornos no momento atual (Harvey, 1991; Sassen, 1998). Por um lado, a organização de uma cadeia transnacional de valorização financeira reitera antigas centralidades, alçando os principais centros de acumulação do mundo à condição de cidades globais especializadas na gestão e coordenação dos investimentos (Sassen, 1998). Por outro, a constituição de um mercado global - marcado pela unicidade dos sistemas técnicos e a unificação do tempo (Santos, 2013) - encurtou distâncias, adensou as redes de conexão entre lugares e países, fortalecendo novas frentes de crescimento econômico (Harvey, 1991; Sassen, 1998) que redesenharam o equilíbrio global de poder (Manrique, 2012).

No bojo da reestruturação produtiva conduzida pelo capital financeiro (Harvey, 1991; Sassen, 1998), o final do século XX e começo do XXI marcam a paulatina desindustrialização dos países desenvolvidos conjuntamente à transformação do sudeste asiático, sobretudo a China, na principal fábrica do mundo e numa voraz consumidora de matérias-primas, historicamente produzidas nos países do Sul Global (Manrique, 2012). Por essa razão, o chamado efeito China tem relações diretas no aumento das relações comerciais Sul-Sul (Manrique, 2012) e na emergência da chamada 'agroinflação'11 (Hage, Peixoto, Vieira Filho, 2012). Na condição de um dos maiores produtores de commodities do mundo, o Brasil passou por acelerado crescimento econômico, principalmente entre 2002 e 2014 (Bredow, Lélis, Cunha, 2016), com desdobramentos importantes quanto à dinâmica de sua inserção internacional (Manrique, 2012; Visentini, 2010).

Segundo Visentini (2010), a virada para o Sul fez da África um das protagonistas nas relações exteriores brasileiras, fenômeno potencializado pela existência de laços coloniais e acordos bilaterais que datam dos anos 1960. Além do Programa de Estudantes Convênio para graduação e pós-graduação (PEC-G e PEC-PG), com atuação importante nos países africanos falantes de língua portuguesa (Gusmão, 2012), a presença brasileira na África se fez através da ação tanto de estatais, como a Petrobrás e a Embrapa, quanto via capitais privados, os quais atuaram principalmente no ramo de fabricação de cimento e de remédio, construção de ferrovias, exploração de carvão,

Entende-se que o crescimento significativo da população mundial, a maior demanda por alimentos, os efeitos climáticos adversos, a precariedade dos estoques reguladores, o crescimento econômico registrado pelos mercados emergentes, a elevação dos preços do petróleo e o avanço da produção de biocombustíveis, condicionaram a surpreendente valorização dos preços agrícolas ao longo da primeira década do século XXI, mesmo diante da crise financeira de 2008 (Hage, Peixoto, Vieira Filho, 2012). 
exportação de aparelhos celulares, montagem de ônibus e venda de máquinas de coletar lixo, entre outros (Visentini, 2010).

A proliferação dessas conexões globais intensificou a produção das condições materiais e subjetivas necessárias à construção da migração como fenômeno social (Sassen, 2010), desdobrando-se em uma multiplicidade de modalidades migratórias (Wenden, 2001): estudantes, trabalhadores de empresas multinacionais, missionários religiosos e refugiados (Gusmão, 2012). Essa variedade de tipos de migração desafia os paradigmas convencionais (Gusmão, 2012), rompe com as explicações fundamentadas nos fatores de expulsão e atração (Sassen, 2010), inserindo-se no arcabouço teórico das migrações transnacionais Sul-Sul (Baeninger, 2014; Phelps, 2014).

De acordo com Phelps (2014), o recente aumento dos fluxos Sul-Sul deve-se, também, às políticas migratórias cada vez mais restritivas do Norte Global. Para o autor, a alta seletividade imposta pela legislação de tais países faz das migrações Sul-Sul menos seletivas e mais temporárias, haja vista o destino desejado continuar sendo o Norte. As contribuições de Phelps (2014), somadas à discussão proposta por Gusmão (2012), reiteram a extrema diversidade da migração Brasil-África e a necessidade de abordagens que reforcem essa dimensão (Gusmão, 2012).

Nesse sentido, ao destacar a dimensão espacial como recurso fundamental à apreensão das diversas conexões escalares da migração (Guarnizo et alii, 2013; Glick Schiller, 2007), o transnacionalismo avança por incorporar o caráter eminentemente heterogêneo e multifacetado dos processos migratórias contemporâneos (Baeninger, 2014). Ademais, como perspectiva crítica ao nacionalismo metodológico, esse aporte ilumina o conjunto de relações sociais que, estruturadas no âmbito da divisão internacional do trabalho, se reconfiguram a nível individual e na esfera da localidade (Glick Schiller, 2007). Desde esse olhar, as migrações transnacionais (Baeninger, 2014) assumem a diversidade de lógicas e modalidades migratórias, os conflitos entre os interesses do Estado-Nação e das corporações, o encurtamento (seletivo) das distâncias material e subjetiva entre os lugares, as contradições entre agência e estrutura, micro e macro, a questão das remessas, das identidades entre dois países, da não-integração ou da incorporação sempre parcial do migrante (Baeninger, 2014; Glick Schiller, 2007; Sassen, 2010; Guarnizo et alii, 2013).

À luz dessa bibliografia, os imigrantes africanos no Brasil (Gusmão, 2012) compartilham das especificidades das migrações transnacionais Sul-Sul (Baeninger, 2014; Phelps, 2014), emergindo como processo social que expressa claramente o que Basso (2003 apud Baeninger, Peres, 2017, p. 125) identifica como periféricos na periferia: "um movimento geopolítico 
transnacional em que à periferia do capital dirigir-se-ão, cada vez mais, os fluxos dos países periféricos". Ou seja, processos multifacetados que levam a movimentos populacionais entre países considerados do Sul Global (Manrique, 2012), nesse caso, desde o continente africano para o Brasil (Domeniconi et alii, 2018).

A partir dessa bibliografia, o presente trabalho discute a migração transnacional africana em território brasileiro em suas múltiplas modalidades (Wenden, 2001): estudantes (Gusmão, 2012), sacerdotes, trabalhadores qualificados (Domeniconi, Baeninger, 2016), mulheres, crianças, refugiados e solicitantes (Baeninger, 2017). Da análise dos registros administrativos da Política Federal, do Comitê Nacional para Refugiados e do Ministério do Trabalho, embora insuficiente à compreensão das complexidades que perpassam o fenômeno (Gusmão, 2012), emergem uma ampla agenda de pesquisa: questões de família, gênero e geração, contradições na inserção laboral, novas estratégias de entrada e permanência no país e as migrações internas das migrações internacionais.

\section{O uso dos registros administrativos na análise das imigrações internacionais}

A intensidade das mudanças, dos sentidos e das modalidades migratórias (Wenden, 2001) que perpassam o fluxo de africanos no Brasil requer a exploração de fontes alternativas ao censo demográfico ${ }^{2}$, cuja periodicidade não acompanha as rápidas recomposições do fenômeno (Baeninger et alii, 2017). Por essa razão, o uso de registros administrativos tem crescido significativamente, a despeito dos problemas de coleta, sistematização, atualização e divulgação dessas bases. Dentre os principais registros utilizados no estudo das migrações internacionais, destacam-se o Sistema Nacional de Cadastros e Registros (SINCRE), da Política Federal, do Comitê Nacional para Refugiados (CONARE), do Ministério da Justiça, e a Relação Anual de Informações Sociais (RAIS), do Ministério da Economia (Baeninger et alii, 2017).

Os registros da Política Federal, produzidos no âmbito do Sistema de Cadastramento de Registro de Estrangeiro (SINCRE) e disponibilizados pelo Observatório das Migrações Internacionais (OBMigra), contemplam todos os imigrantes internacionais com Registro Nacional de Estrangeiro (RNE). Por permitir identificação dos amparos legais que garantem a permanência dos/ das imigrantes no país, país de nascimento, unidade da federação de ingresso,

\footnotetext{
Ainda que o Censo Demográfico seja a única fonte de informações que contemple o total da população residente no país, seus dados encontram-se hoje com uma defasagem de quase nove anos, período no qual o país apresentou importantes mudanças em suas dinâmicas migratórias (Baeninger et alii, 2017).
} 
entre outras variáveis, essa fonte será amplamente explorada na pesquisa. Vale destacar, no entanto, que, essa fonte de informação não é capaz de estimar o total de imigrantes internacionais residentes no país. Uma vez emitido o RNE, a pessoa permanece na base do SINCRE mesmo tendo deixado o país tempos depois. A essa limitação, somam-se os problemas de preenchimento, publicidade e acesso $^{3}$, a não consideração dos indocumentados ${ }^{4}$ e dos solicitantes de refúgio.

A lacuna com relação à situação dos solicitantes de refúgio - pessoas não incluídas nessa base e cujo fluxo tem aumento significativamente nos últimos anos - conduz a exploração de outro registro: o do Comitê Nacional para Refugiados (CONARE), vinculado ao Ministério da Justiça. Mesmo em caráter provisório, aos solicitantes de refúgio é garantido o direito de acesso ao Cadastro de Pessoa Física (CPF) e Carteira de Trabalho e Previdência Social (CPTS), com possibilidade de inserção no mercado de trabalho formal.

Por fim, os registros administrativos do Ministério da Economia (Relação Anual de Informações Sociais e Cadastro de Empregados e Desempregados) derivam das declarações obrigatórias que empresas registradas no Cadastro Nacional de Pessoas Jurídicas (CNPJ) fazem anualmente junto ao sistema eletrônico do Ministério do Trabalho brasileiro. A base contempla todos os registros de trabalho no mercado formal em 31 de dezembro do ano de referência. As informações disponíveis apresentam periodicidade anual e abrangência nacional, sendo possível desagregá-las até o nível municipal. Por sua compatibilização com a Classificação Brasileira de Ocupação e periodicidade, tais fontes se destacam como principal fonte de informação sobre dinâmica do mercado de trabalho formal brasileiro. Dentre as limitações observadas nota-se que: há possibilidade de dupla-contagem do trabalhador que apresente mais de um registro de trabalho ativo; a não abrangência do mercado de trabalho autônomo e informal e possíveis erros de preenchimento do formulário online (Baeninger et alii, 2017).

No conjunto, essas fontes de informação possibilitam um melhor acompanhamento dos principais fluxos imigratórios para o Brasil, sobretudo no período intercensitário. Por essa razão, são amplamente exploradas nesse trabalho.

\footnotetext{
As informações do SINCRE passaram a ser de consulta pública apenas em 2017.

4 É importante destacar o crescente acesso à documentação na dinamização dos fluxos migratórios internacionais recentes para o Brasil (Fernandes et alii, 2014). Seja em função de acordos multilaterais (tais como os firmados entre os países do Mercado Comum do Sul), das concessões especiais de visto (como o visto de ajuda humanitária conferido aos haitianos), ou das garantias previstas a todos os solicitantes de refúgio, Fernandes et alii (2014) pontuam a diminuição considerável de imigrantes internacionais em situação de indocumentação.
} 


\section{Os registros administrativos da Polícia Federal: uma análise do} Sistema Nacional de Cadastros e Registros de Estrangeiros (SINCRE)

As informações da Tabela 1 corroboram o incremento da imigração internacional no Brasil, com uma taxa de crescimento de emissão de Registro Nacional de Estrangeiro (RNE) de 9\% a.a., entre 2000 e 2017. Para os africanos, esse ritmo foi de $11,5 \%$ a.a., o que representa mais de 52 mil registros efetuados no período considerado (Tabela 1).

Tabela 1 - Registros de africanos e total de registros de imigrantes internacionais (Registro Nacional de Estrangeiro - RNE) no Brasil, entre 2000 e 2017, segundo ano de registro

\begin{tabular}{|c|c|c|c|}
\hline Ano & Total de registros & Registros de africanos & $\%$ \\
\hline 2000 & 23.337 & 1.182 & 5,1 \\
\hline 2001 & 20.819 & 794 & 3,8 \\
\hline 2002 & 21.992 & 966 & 4,4 \\
\hline 2003 & 25.838 & 993 & 3,8 \\
\hline 2004 & 27.415 & 1.210 & 4,4 \\
\hline 2005 & 33.421 & 1.617 & 4,8 \\
\hline 2006 & 45.223 & 1.760 & 3,9 \\
\hline 2007 & 39.802 & 1.773 & 4,5 \\
\hline 2008 & 40.397 & 2.084 & 5,2 \\
\hline 2009 & 88.439 & 5.368 & 6,1 \\
\hline 2010 & 55.461 & 3.705 & 4,9 \\
\hline 2011 & 76.463 & 2.856 & 3,7 \\
\hline 2012 & 102.280 & 3.549 & 3,5 \\
\hline 2013 & 114.065 & 3.580 & 3,1 \\
\hline 2014 & 99.542 & 4.170 & 4,2 \\
\hline 2015 & 114.473 & 5.646 & 4,9 \\
\hline 2016 & 125.465 & 4.951 & 3,9 \\
\hline 2017 & 102.721 & 7.524 & 7,3 \\
\hline Total & 1.157 .043 & 52.728 & 4,6 \\
\hline $\begin{array}{c}\text { Taxa geomátrica de } \\
\text { crescimento dos registros } \\
\text { entre } 2000 \text { e } 2017 \text { (em \% a.a.) }\end{array}$ & 9,1 & 11.5 & \\
\hline
\end{tabular}

Fonte: Sistema Nacional de Cadastros e Registros (SINCRE), OBMigra. Tabulações Observatório das Migrações em São Paulo- NEPO/UNICAMP. 
Sobretudo entre 2004 e 2015, verifica-se um crescimento paulatino e sustentado das emissões de RNEs para africanos residentes no Brasil. Em 2009, o pico de registros está associado aos efeitos da Lei 6.815, de 2 de julho de 2009 (Lei da Anistia), que disciplina a concessão de visto de residência provisório para o estrangeiro em situação indocumentada (Fernandes et alii, 2014). De mesmo modo, a diminuição no volume de registros entre 2015 e 2016, e seu subsequente aumento em 2017, pode espelhar os efeitos da importância crescente de solicitantes de refúgio na composição do fluxo (Baeninger et alii, 2018; Baeninger, 2017).

Gráfico 1 - Imigrantes africanos registrados (Registro Nacional de Estrangeiro - RNE) no Brasil, entre 2000 e 2017, segundo ano de registro

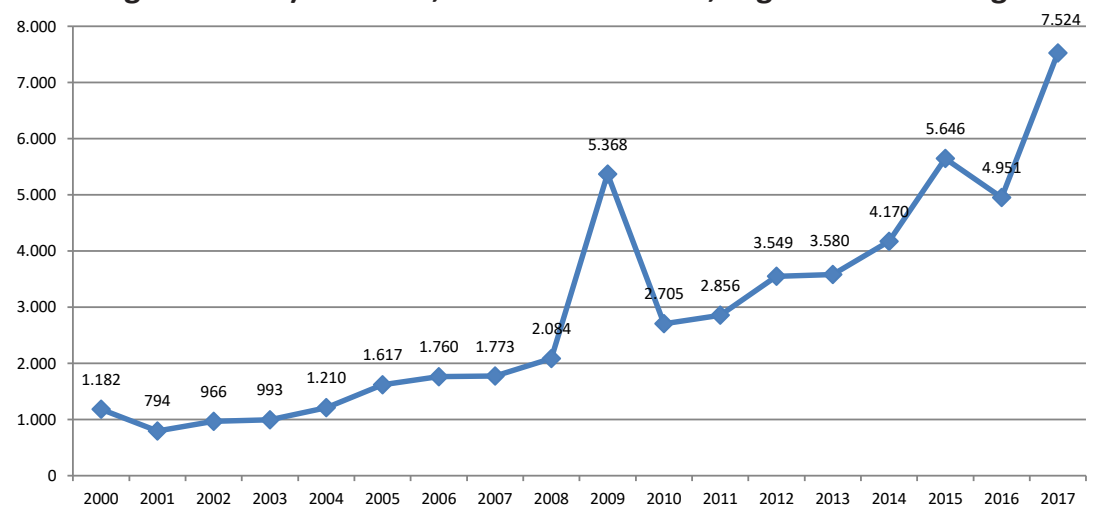

Fonte: Sistema Nacional de Cadastros e Registros (SINCRE), OBMigra. Tabulações Observatório das Migrações em São Paulo- NEPO/UNICAMP.

O SINCRE evidencia, ainda, a extrema diversidade de países desses imigrantes: mais de 50 Estados-Nacionais diferentes. Angola constitui o principal fluxo, com quase 13.500 imigrantes registrados no período, o que representa $30 \%$ do total de registros (Tabela 2). Outros países importantes são: Cabo Verde, Guiné-Bissau, Nigéria, Moçambique, Senegal, África do Sul, República Democrática do Congo, Marrocos e Egito. Vale registrar o significativo crescimento de países que, no ano 2000, quase não apareciam no SINCRE, como Líbia, Benin e Costa do Marfim (Tabela 2). 


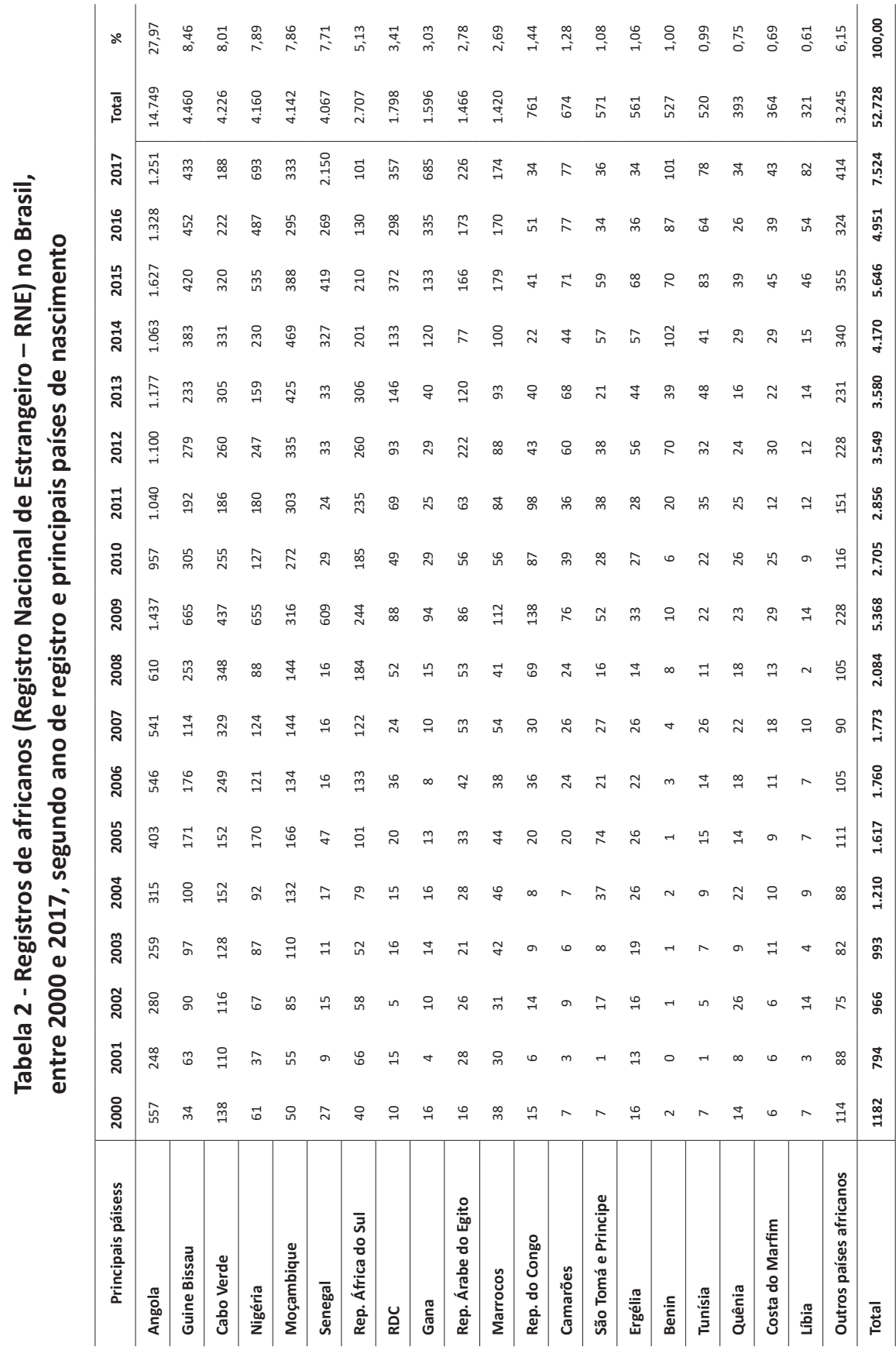

Fonte: Sistema Nacional de Cadastros e Registros (SINCRE), OBMigra. Tabulações. Observatório das Migrações em São Paulo- NEPO/UNICAMP. 
Com relação aos principais amparos legais que garantem o direito de residência no Brasil, o mais recorrente diz respeito à concessão de visto temporário para estudante: 17.334 registros no artigo 13, IV, Lei 8.615 e 1.554 casos referentes ao inciso I dessa mesma lei (Quadro 1). Juntos, esses dispositivos jurídicos representam quase $38 \%$ de todos os amparos legais utilizados na regulação da imigração de africanos para o Brasil, no período considerado. Reunificação familiar, anistia aos indocumentados ${ }^{5}$, permissão de residência para cientistas, professores ou técnicos e missionários religiosos estão entre as outras legislações recorrentes (Quadro 1).

\section{Quadro 1 - Imigrantes africanos registrados (Registro Nacional de Estrangeiro - RNE) no Brasil, entre 2000 e 2017, segundo principais amparos legais}

\begin{tabular}{|c|c|c|c|}
\hline Amparo legal & Descrição do amparo legal & Total & $\%$ \\
\hline $\begin{array}{l}\text { Artigo } 13 \text {, IV, Lei } 6.815 \\
\text { de } 1980 \text { (Estatuto do } \\
\text { Estrangeiro) }\end{array}$ & $\begin{array}{l}\text { Define a concessão de visto temporário ao } \\
\text { estrangeiro que pretenda vir ao Brasil na condição de } \\
\text { estudante. }\end{array}$ & 17.334 & 32,9 \\
\hline $\begin{array}{l}\text { Artigo } 1 \text { da Resolução } \\
\text { Normativa } 108 \text { de } \\
2014 \text { do CNlg }\end{array}$ & $\begin{array}{l}\text { Dispõe sobre a concessão de visto temporário ou } \\
\text { permanente e permanência definitiva a título de } \\
\text { reunião familiar. }\end{array}$ & 7.908 & 15,0 \\
\hline $\begin{array}{l}\text { Artigo } 75 \text {, II, Lei } 6.815 \\
\text { de } 1980 \text { (Estatuto do } \\
\text { Estrangeiro) }\end{array}$ & $\begin{array}{l}\text { Define a não possibilidade de expulsão do território } \\
\text { nacional quando o estrangeiro tiver: a) Cônjuge } \\
\text { brasileiro do qual não esteja divorciado ou separado, } \\
\text { de fato ou de direito, e desde que o casamento tenha } \\
\text { sido celebrado há mais de } 5 \text { (cinco) anos; ou b) filho } \\
\text { brasileiro que, comprovadamente, esteja sob sua } \\
\text { guarda e dele dependa economicamente. }\end{array}$ & 4.912 & 9,3 \\
\hline $\begin{array}{l}\text { Artigo } 13, \text { V, Lei } 6.815 \\
\text { de } 1980 \text { (Estatuto do } \\
\text { Estrangeiro) }\end{array}$ & $\begin{array}{l}\text { Define a concessão de visto temporário ao } \\
\text { estrangeiro que pretenda vir ao Brasil na condição de } \\
\text { cientista, professor, técnico ou profissional de outra } \\
\text { categoria, sob regime de contrato ou a serviço do } \\
\text { Governo brasileiro. }\end{array}$ & 4.463 & 8,5 \\
\hline $\begin{array}{l}\text { Resolução Normativa } \\
27 \text { de } 1998 \text { do CNIg }\end{array}$ & $\begin{array}{l}\text { Disciplina a avaliação de situações especiais e casos } \\
\text { omissos pelo Conselho Nacional de Imigração. }\end{array}$ & 3.951 & 7,5 \\
\hline Lei 11.961 de 2009 & $\begin{array}{l}\text { Dispõe sobre a residência provisória para o } \\
\text { estrangeiro em situação irregular no território } \\
\text { nacional e dá outras providências. }\end{array}$ & 2.743 & 5,2 \\
\hline $\begin{array}{l}\text { Lei } 9.474 \text {, de } \\
1997 \text { (Estatuto do } \\
\text { Refugiado) }\end{array}$ & $\begin{array}{l}\text { Define mecanismos para a implementação do } \\
\text { Estatuto dos Refugiados de 1951, e determina outras } \\
\text { providências. }\end{array}$ & 2.061 & 3,9 \\
\hline $\begin{array}{l}\text { Artigo } 13 \text {, I, Lei } 6.815 \\
\text { de } 1980 \text { (Estatuto do } \\
\text { Estrangeiro) }\end{array}$ & $\begin{array}{l}\text { Disciplina a concessão de visto temporário ao } \\
\text { estrangeiro que pretenda vir ao Brasil em viagem } \\
\text { cultural ou em missão de estudos }\end{array}$ & 1.554 & 2,9 \\
\hline
\end{tabular}

A anistia concedida em 2009 beneficiou mais de 2.500 africanos em situação irregular no Brasil (Quadro 1). Isso explica o salto no número de registros para esse ano, conforme apontado no Gráfico 1. 


\begin{tabular}{l|l|c|c}
\hline Resolução Normativa & $\begin{array}{l}\text { Concessão de visto temporário ou permanente a } \\
\text { título de reunião familiar aos dependentes legais } \\
\text { de cidadão brasileiro ou de estrangeiro residente } \\
\text { temporário ou permanente no País, maior de } 21 \\
\text { anos. }\end{array}$ & 1.250 & 2,4 \\
\hline & \multicolumn{1}{|l|}{ Todos os amparos legais } & 52.728 & 100 \\
\hline
\end{tabular}

Fonte: Sistema Nacional de Cadastros e Registros (SINCRE), OBMigra. Tabulações Observatório das Migrações em São Paulo- NEPO/UNICAMP.

Vale mencionar a resolução normativa referentes às situações especiais e casos omissos (quase 4 mil registros), dispositivo jurídico que evidencia o anacronismo do Estatuto do Estrangeiro frente às características da imigração transnacional de africanos para o Brasil. Para Araújo (2016), diante das lacunas deixadas por essa legislação, "promulgada ainda no regime militar brasileiro, o CNIg [Conselho Nacional de Imigração] vem [...] dedicando boa parte de suas atividades a atuar frente aos casos não previstos em lei"6.

Por fim, destaca-se ainda o amparo legal condizente ao Estatuto do Refugiado, o que reitera uma dimensão fundamental do fenômeno em estudo: a violação grave e generalizada dos direitos humanos e a necessidade de uma proteção jurídica específica (Baeninger, 2017).

Esses diferentes amparos legais iluminam a pluralidade de situações envolvendo a migração africana no Brasil e, portanto, ajudam na construção de suas diferentes modalidades migratórias (Wenden, 2001).

A informação de ocupação reitera a centralidade dos estudantes no total de registros (Tabela 3). O volume considerável de ocupação não classificada e sem ocupação pode ser indicador da crescente precarização das relações de trabalho. Por outro lado, os registros de diretores, gerentes ou proprietários, professores e médicos evidenciam também a migração qualificada (Domeniconi, Baeninger, 2016) como modalidade migratória de destaque (Tabela 3).

6 Em novembro de 2018 é promulgado, finalmente, uma Nova Lei de Migração, considerado um instrumento jurídico muito mais adequado à realidade brasileira (Assis, 2018). 
Tabela 3 - Registros de imigrante africanos (Registro Nacional de Estrangeiro - RNE) no Brasil, entre 2000 e 2016, segundo ano de registro e ocupação

\begin{tabular}{|c|c|c|c|c|c|c|c|c|c|c|c|c|c|c|c|c|c|c|}
\hline Ocupação & 2000 & 2001 & 2002 & 2003 & 2004 & 2005 & 2006 & 2007 & 2008 & 2009 & 2010 & 2011 & 2012 & 2013 & 2014 & 2015 & 2016 & Total \\
\hline Estudante & 434 & 367 & 464 & 442 & 560 & 779 & 839 & 949 & 1208 & 2180 & 1550 & 1474 & 1652 & 1612 & 1928 & 1892 & 1548 & 19878 \\
\hline $\begin{array}{l}\text { Outra } \\
\text { ocupação } \\
\text { não } \\
\text { classificada }\end{array}$ & 54 & 29 & 37 & 42 & 51 & 55 & 61 & 68 & 75 & 539 & 161 & 259 & 204 & 262 & 319 & 627 & 601 & 3444 \\
\hline $\begin{array}{l}\text { Vendedor } \\
\text { ou } \\
\text { empregado } \\
\text { de casa } \\
\text { comercial }\end{array}$ & 91 & 17 & 19 & 28 & 36 & 44 & 30 & 31 & 19 & 453 & 54 & 43 & 107 & 86 & 140 & 357 & 319 & 1874 \\
\hline Oficial & 17 & 4 & 16 & 8 & 17 & 37 & 29 & 51 & 99 & 193 & 132 & 160 & 374 & 244 & 242 & 146 & 93 & 1862 \\
\hline $\begin{array}{l}\text { Diretor, } \\
\text { gerente ou } \\
\text { proprietário }\end{array}$ & 62 & 45 & 54 & 61 & 82 & 123 & 124 & 119 & 100 & 174 & 80 & 94 & 110 & 93 & 72 & 177 & 133 & 1703 \\
\hline Sacerdote & 48 & 32 & 33 & 52 & 60 & 53 & 64 & 71 & 49 & 74 & 61 & 68 & 100 & 122 & 147 & 161 & 137 & 1332 \\
\hline Professor & 49 & 33 & 50 & 38 & 57 & 67 & 72 & 50 & 50 & 170 & 46 & 44 & 75 & 93 & 138 & 125 & 111 & 1268 \\
\hline $\begin{array}{l}\text { Sem } \\
\text { ocupação }\end{array}$ & 7 & 5 & 8 & 5 & 8 & 5 & 25 & 13 & 14 & 58 & 30 & 35 & 100 & 141 & 101 & 320 & 339 & 1214 \\
\hline $\begin{array}{l}\text { Prendas } \\
\text { domesticas }\end{array}$ & 58 & 42 & 54 & 43 & 50 & 59 & 64 & 65 & 53 & 105 & 79 & 65 & 54 & 57 & 31 & 108 & 85 & 1072 \\
\hline Arquiteto & 34 & 31 & 41 & 29 & 35 & 57 & 68 & 35 & 46 & 73 & 53 & 103 & 109 & 121 & 75 & 0 & 0 & 910 \\
\hline $\begin{array}{l}\text { Profissional } \\
\text { liberal }\end{array}$ & 13 & 14 & 6 & 8 & 11 & 19 & 15 & 14 & 17 & 316 & 31 & 28 & 62 & 117 & 35 & 66 & 55 & 827 \\
\hline Medico & 11 & 17 & 14 & 21 & 23 & 35 & 36 & 33 & 57 & 48 & 50 & 53 & 48 & 72 & 46 & 53 & 48 & 665 \\
\hline Pedreiro & 40 & 5 & 5 & 8 & 5 & 3 & 8 & 3 & 6 & 75 & 15 & 22 & 22 & 35 & 92 & 140 & 106 & 590 \\
\hline Economista & 17 & 15 & 14 & 19 & 20 & 32 & 19 & 13 & 21 & 34 & 22 & 21 & 34 & 30 & 26 & 94 & 61 & 492 \\
\hline Mecânico & 26 & 12 & 5 & 5 & 5 & 10 & 19 & 16 & 8 & 53 & 10 & 12 & 50 & 32 & 51 & 85 & 85 & 484 \\
\hline Barbeiro & 2 & 2 & 2 & 11 & 7 & 18 & 12 & 9 & 8 & 97 & 17 & 23 & 24 & 25 & 22 & 77 & 93 & 449 \\
\hline $\begin{array}{l}\text { Menor } \\
\text { (criança, } \\
\text { não } \\
\text { estudante) }\end{array}$ & 12 & 12 & 14 & 9 & 16 & 17 & 19 & 15 & 30 & 27 & 22 & 30 & 26 & 28 & 23 & 84 & 48 & 432 \\
\hline Aposentado & 9 & 7 & 12 & 16 & 23 & 36 & 32 & 24 & 31 & 40 & 28 & 33 & 20 & 23 & 18 & 40 & 25 & 417 \\
\hline $\begin{array}{l}\text { Dependente } \\
\text { de titular }\end{array}$ & 2 & 2 & 1 & 3 & 7 & 10 & 20 & 22 & 40 & 35 & 23 & 35 & 42 & 54 & 45 & 40 & 32 & 413 \\
\hline Cozinheiro & 14 & 2 & 3 & 9 & 2 & 4 & 10 & 3 & 7 & 52 & 10 & 6 & 29 & 18 & 21 & 91 & 89 & 370 \\
\hline Bolsista & 2 & 3 & 1 & 1 & 1 & 10 & 5 & 11 & 11 & 32 & 13 & 24 & 32 & 26 & 113 & 50 & 31 & 366 \\
\hline $\begin{array}{l}\text { Outras } \\
\text { ocupações }\end{array}$ & 178 & 94 & 112 & 134 & 134 & 141 & 189 & 157 & 135 & 537 & 213 & 221 & 266 & 276 & 472 & 897 & 910 & 5066 \\
\hline
\end{tabular}

Fonte: Sistema Nacional de Cadastros e Registros (SINCRE), OBMigra. Tabulações Observatório das Migrações em São Paulo- NEPO/UNICAMP.

Nota: para o ano de 2017, não foi divulgado as informações sobre ocupação no SINCRE. 
No tocante à composição por idade e sexo, é evidente a maior participação de homens entre os 25 e 40 anos (Gráfico 2). Para os anos de 2015 e 2016, nota-se aumento na proporção de crianças, o que pode representar os efeitos da reunificação familiar. Em 2017, além da participação importante de crianças, verifica-se a redução da proporção de mulheres e rejuvenescimento do fluxo: ambos os fenômenos são efeitos do aumento da participação de homens entre 25 e 35 anos (Gráfico 2).

Gráfico 2 - Imigrantes africanos registrados (Registro Nacional de Estrangeiro - RNE) no Brasil, entre 2000 a 2014, 2015, 2016 e 2017, segundo idade e sexo

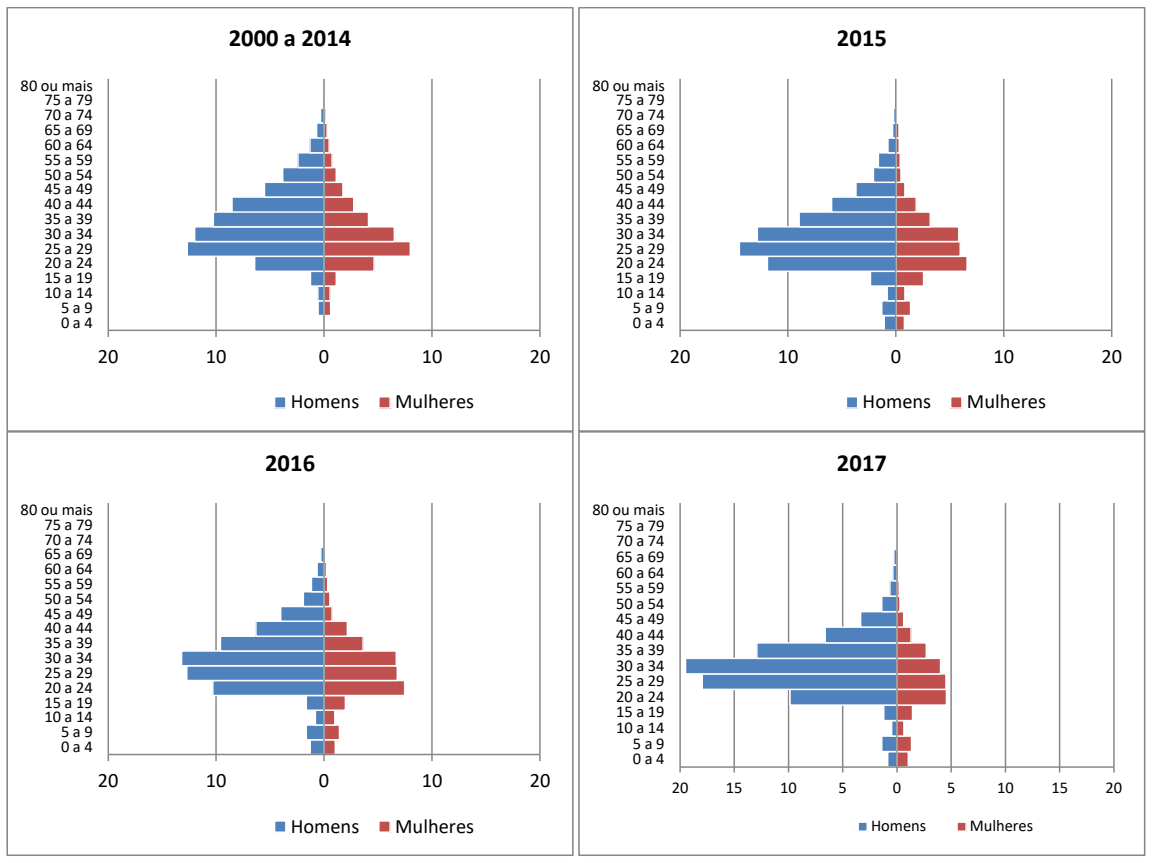

Fonte: Sistema Nacional de Cadastros e Registros (SINCRE), OBMigra. Tabulações.

Observatório das Migrações em São Paulo- NEPO/UNICAMP.

Em se tratando do local de residência no Brasil declarado no registro, entre 2000 e 2017, observa-se a diminuição da centralidade do Sudeste: essa região, que era residência especificada em $77 \%$ dos registros em 2000, diminui para 55\%, em 2017 (Gráfico 3). Ao mesmo tempo, é nítido o aumento da participação do Sul, que passou de 9\% para 26,7\% (Gráfico 3).

A consolidação de outros espaços da migração africana em território brasileiro, para além do sudeste, ocorre paralelamente à emergência dos estados fronteiriços do norte do país como porta de entrada desses imigrantes. Segundo as informações sistematizadas no Gráfico 4, o ingresso via Região 
Norte, praticamente inexistente em 2000, passa a representar $21,5 \%$ dos registros em 2017.

Gráfico 3 - Proporção de emigrante africanos registrados (Registro Nacional de Estrangeiro - RNE) no Brasil, entre 2000 e 2017, segundo ano de registro e regiões de residência

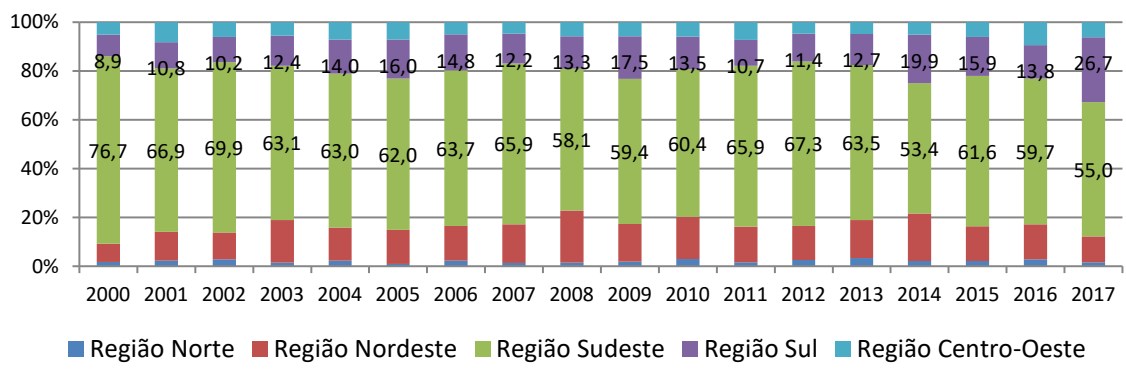

Fonte: Sistema Nacional de Cadastros e Registros (SINCRE), OBMigra.

Tabulações Observatório das Migrações em São Paulo- NEPO/UNICAMP.

\section{Gráfico 4 - Proporção de emigrante africanos registrados (Registro Nacional de Estrangeiro - RNE) no Brasil, entre 2000 e 2017, segundo ano de registro e regiões de entrada no país}

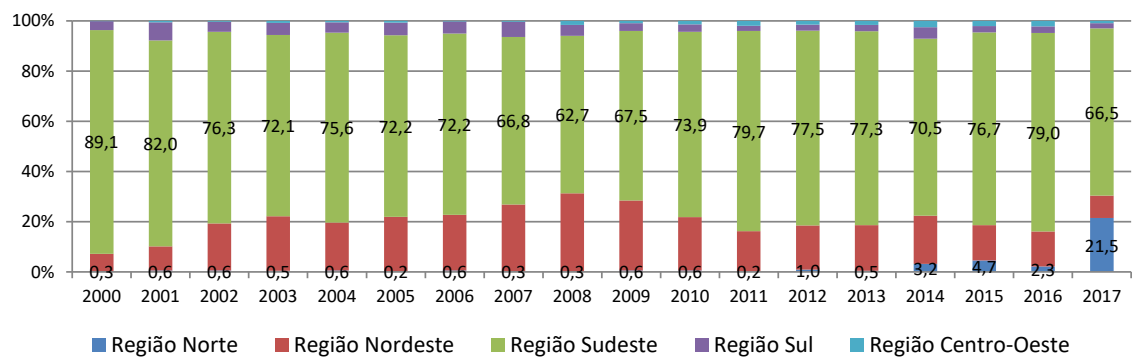

Fonte: Sistema Nacional de Cadastros e Registros (SINCRE), OBMigra.

Tabulações Observatório das Migrações em São Paulo- NEPO/UNICAMP.

Para Baeninger (2018), a entrada no Brasil via fronteira norte associa-se às formas de travessia terrestres, às redes de coiotes e de tráfico de pessoas. Em sua interpretação, a permeabilidade das fronteiras brasileiras contribui para a redefinição desses espaços frente à inserção do Brasil na rota das migrações transnacionais (Baeninger, 2018). Essa reconfiguração da fronteira inicia-se com a imigração haitiana, em meados de 2013, e se desdobra, nos últimos anos, na presença de imigrantes de países como Senegal, República Democrática do Congo, Nigéria, Guiné, Serra Leoa, Cabo Verde, Cuba e Venezuela (Silva, 2017; Santos, 2018; Baeninger, 2018). Nesse novo contexto, as fronteiras brasileiras - em especial a Norte - passam a envolver movimentos migratórios 
com ou sem relações históricas e que respondem ou não às relações entre países vizinhos de forma a estabelecer novas faces dos "fluxos migratórios transnacionais oriundos do Sul Global" (Baeninger, 2018, p. 463). Segundo a autora,

É nesse cenário que a produção social de espaços da migração Sul-Sul na fronteira redesenha, do norte ao sul do Brasil, o entendimento das migrações fronteiriças. De um lado, seguem como áreas de circulação e trânsito cotidiano, mas de outro lado, se tornam áreas de recepção de imigrantes caribenhos, africanos e refugiados bem como áreas de trânsito para outros destinos no país e fora dele. (Baeninger, 2018, p. 463)

Baeninger (2018) considera que um dos principais sintomas da reconfiguração da dinâmica migratória nas fronteiras terrestres brasileiras envolve a perspectiva de entendimento desse espaço enquanto uma fronteira global que não se traduz, necessariamente, em um espaço de direitos. A autora entende, portanto, que um dos importantes desdobramentos desse cenário é o incremento das solicitações de refúgio (Baeninger, 2018), fato que conduz à exploração de uma nova fonte de informação: os registros do Comitê Nacional para Refugiados (CONARE), órgão vinculado ao Ministério da Justiça, criado em 1997 por força da Lei 9.474 (Estatuto do Refugiado) ${ }^{7}$. A seguir, apresenta-se uma breve discussão dessa base.

\section{Os registros administrativos do Comitê Nacional para Refugiados}

Entre 1999 e 2018, as solicitações de refúgio recebidas pelo CONARE cresceram 42\% a.a.: enquanto no ano de 1999 houve apenas 99 solicitações, no ano de 2018, registrou-se quase 80 mil (Tabela 4). Esse aumento acelerado deveu-se, principalmente, ao fluxo de haitianos, de fins de 2010 (Baeninger et alii, 2016), e, mais recentemente, de venezuelanos, nacionalidade que chega a representar metade dos mais de 160 mil pedidos de refúgio encaminhados para o CONARE (Tabela 4; Baeninger, Silva, 2018).

Para esse mesmo período, a taxa de crescimento de solicitações de refúgio por africanos é de 25,42\% a.a., representando quase $20 \%$ do total de solicitações (Tabela 4). Verifica-se incremento importante do fluxo a partir de 2013, quando o volume de pedidos ultrapassa a casa de mil por ano, com picos de chegam a 6 mil, em 2014 e 2017.

\footnotetext{
O Comitê Nacional para Refugiados (CONARE) foi instituído em 1997, no bojo da Lei 9.474 (Estatuto do Refugiado), promulgada nesse mesmo ano. Antes disso, o Alto Comissariado para Refugiado das Nações Unidos responsabilizava-se pelo recebimento e análise dos processos de refúgio no Brasil (Dominguez, Baeninger, 2006).
} 
Tabela 4 - Solicitações de refúgio de africanos recebidas pelo ACNUR (até 1997) e CONARE (desde 1997) no Brasil, segundo principais nacionalidades, 1994 a 2018

\begin{tabular}{|c|c|c|c|}
\hline Ano da solicitação & $\begin{array}{c}\text { Total de } \\
\text { solicitações }\end{array}$ & $\begin{array}{c}\text { Solicitações de } \\
\text { africanos }\end{array}$ & $\%$ \\
\hline 1994 & 3 & 0 &.. \\
\hline 1999 & 99 & 47 & 47,5 \\
\hline 2000 & 128 & 106 & 82,8 \\
\hline 2001 & 32 & 19 & 59,4 \\
\hline 2002 & 332 & 76 & 22,9 \\
\hline 2003 & 158 & 99 & 62,7 \\
\hline 2004 & 42 & 19 & 45,2 \\
\hline 2005 & 10 & 3 & 30,0 \\
\hline 2006 & 534 & 124 & 23,2 \\
\hline 2007 & 259 & 72 & 27,8 \\
\hline 2008 & 410 & 210 & 51,2 \\
\hline 2009 & 505 & 110 & 21,8 \\
\hline 2010 & 621 & 178 & 28,7 \\
\hline 2011 & 1.479 & 358 & 24,2 \\
\hline 2012 & 1.350 & 407 & 30,1 \\
\hline 2013 & 6.856 & 2.491 & 36,3 \\
\hline 2014 & 11.128 & 6.231 & 56,0 \\
\hline 2015 & 16.006 & 7.644 & 47,8 \\
\hline 2016 & 8.739 & 2.802 & 32,1 \\
\hline 2017 & 32.030 & 6.332 & 19,8 \\
\hline 2018 & 79.921 & 3.476 & 4,3 \\
\hline Total & 160.642 & 30.804 & 19,2 \\
\hline $\begin{array}{l}\text { Taxa geométrica de } \\
\text { crescimento entre } 1999 \\
\text { e } 2019 \text { (em \% a.a.) }\end{array}$ & 42,23 & 25,42 & \\
\hline
\end{tabular}

Fonte: Comitê Nacional para Refugiados (CONARE), Ministério da Justiça do Brasil, 2019.

Tabulações Observatório das Migrações em São Paulo - NEPO/UNICAMP-Fapesp/CNPq.

Dentre os principais países está Senegal, com quase 28\% das solicitações de africanos (8.520 registros), e Angola, responsável por outros 17\% (ou 5.165 registros) (Tabela 5). Também se destacam Nigéria, Congo, Gana, Guiné Bissau, Guiné, República Democrática do Congo, Togo, Somália, Marrocos, Camarões, Serra Leoa e Mali (Tabela 5). 


\section{Tabela 5 - Solicitações de refúgio de africanos recebidas pelo ACNUR (até 1997) e CONARE (desde 1997) no Brasil, segundo principais nacionalidades, 1999 a 2018}

\begin{tabular}{l|c|c}
\hline Nacionalidade & Total & \% \\
\hline Senegal & 8.520 & 27,7 \\
\hline Angola & 5.165 & 16,8 \\
\hline Nigéria & 3.000 & 9,7 \\
\hline Congo & 2.297 & 7,5 \\
\hline Gana & 2.155 & 7,0 \\
\hline Guiné Bissau & 1.724 & 5,6 \\
\hline Guiné & 890 & 2,9 \\
\hline República Democrática do Congo & 686 & 2,2 \\
\hline Togo & 621 & 2,0 \\
\hline Somália & 579 & 1,9 \\
\hline Marrocos & 523 & 1,7 \\
\hline Camarões & 504 & 1,6 \\
\hline Serra Leoa & 460 & 1,5 \\
\hline Mali & 422 & 1,4 \\
\hline Outros países africanos & 3.258 & 10,6 \\
\hline Total & 30.804 & 10 \\
\hline
\end{tabular}

Fonte: Comitê Nacional para Refugiados (CONARE), Ministério da Justiça do Brasil, 2019. Tabulações Observatório das Migrações em São Paulo - NEPO/UNICAMP-Fapesp/CNPq.

Dos 30.804 pedidos de refúgio de africanos, apenas 10.052 foram analisados pelo CONARE (Tabela 6). Ou seja, até o final do ano de 2018, havia nada menos que 20.752 processos de africanos à espera de uma deliberação da instituição ${ }^{8}$. Do total de casos analisados, 3.701 (36,8\%) foram deferidos, $3.161 \%(31,4 \%)$ foram encaminhados para o Conselho Nacional de Imigração (CNlg) e 2.119 (21\%) foram indeferidos (Tabela 6).

8 De acordo com o Ministério da Justiça e Segurança Pública brasileiro, responsável pela divulgação de informações sobre o CONARE, "Não há um prazo específico para a realização de cada um desses procedimentos. A análise varia de acordo com a nacionalidade dos solicitantes, com a atualização cadastral desses solicitantes (possibilitando contatá-los quando necessário), com a história específica de cada solicitante, com a complexidade do caso, bem como com as informações disponíveis do país de origem. Em média, as solicitações são analisadas em 2 anos, período de tempo que pode variar para mais ou para menos, dependendo das variáveis elencadas" (Brasil, s.a.). Mais informações encontram-se disponíveis em: < https://www.justica. gov.br/seus-direitos/refugio/perguntas-frequentes\# processodereconhecimentodacondicaoderef ugiado >. Acesso em: 01.06.2019. 


\section{Tabela 6 - Solicitações de refúgio de africanos examinadas pelo ACNUR (até 1997) CONARE (a partir de 1997) no Brasil, segundo status do processo}

\begin{tabular}{l|c|c}
\hline Status do processo & Total & \% \\
\hline Casos deferidos & 3.701 & 36,82 \\
\hline Encaminhamento CNIg & 3.161 & 31,45 \\
\hline Casos indeferidos & 2.119 & 21,08 \\
\hline Arquivados & 218 & 2,17 \\
\hline Cessação & 8 & 0,08 \\
\hline Extinção do processo & 804 & 8,00 \\
\hline Perda da condição de refugiado & 26 & 0,26 \\
\hline Erro de lançamento na listagem da plenária & 7 & 0,07 \\
\hline Sem informação & 8 & 0,08 \\
\hline Total de processos examinados & 10.052 & 100 \\
\hline
\end{tabular}

Fonte: Comitê Nacional para Refugiados (CONARE), Ministério da Justiça do Brasil, 2019. Tabulações Observatório das Migrações em São Paulo - NEPO/UNICAMP-Fapesp/CNPq.

A diferença entre o total de pedidos de refúgio registrados e a quantidade de solicitações deferidas pelo CONARE representa o que Baeninger (2017) denomina de crise migratória no destino desse fluxo, expressa tanto pelas restrições, como pela morosidade na aplicação da lei que garante a proteção aos refugiados. Por essa razão, Baeninger (2017) propõe a análise das migrações transnacionais de refúgio como modalidade migratória que contempla tanto refugiados reconhecidos pelo CONARE, como solicitantes, concessões especiais de visto - como o de acolhida humanitária - e até mesmo casos indeferidos, despontando-se como uma migração de crise na origem e no destino migratório. Na origem, estão os condicionantes "econômicos, políticos, civis, religiosos, ideológicos e humanitários" que expulsam determinados grupos sociais (Baeninger, 2017, p. 81). Já no destino, a crise manifesta-se através dos regimes de controle migratório, das restrições à imigração e de suas formas de regulamentação (Baeninger, 2017).

$\mathrm{O}$ incremente de imigrantes africanos no Brasil - seja os que possuem Registro Nacional Estrangeiro, seja os solicitantes de refúgio - suscita a análise da inserção dessas pessoas no mercado de trabalho brasileiro. De modo avançar nesse sentido, a discussão proposta a seguir explora os registros administrativos do Ministério do Trabalho, com estimativas sobre vínculos de trabalho no mercado formal.

\section{Os registros administrativos do Ministério do Trabalho}

Os imigrantes africanos apresentaram uma crescente inserção laboral formal no país, pois contabilizavam 1.170 registros em 2011, 5.098 em 2014 
e alcançaram o patamar de 7.887 vínculos ativos ao final do ano de 2017 (Tabela 7). Ressaltam-se os registros de trabalho de imigrantes angolanos, congoleses, ganeses e senegaleses, os quais, ainda que não discriminados no início do período ${ }^{9}$, têm aumentado crescentemente sua inserção laboral no mercado brasileiro, especialmente entre 2014 e 2017.

Não se deve desconsiderar o importante número de vínculos de imigrantes do continente africano que não se encontram discriminados na base e fazem parte de "outras nacionalidades africanas". A inicial ausência de dados (anteriores a 2011) e posterior crescimento nos registros laborais para esse grupo de imigrantes é em si um fenômeno expressivo do que tange mudanças no perfil, na composição e nas relações sociais e políticas estabelecidas pelos africanos no Brasil.

\section{Tabela 7 - Vínculos de trabalho ativos em 31/12 no mercado formal brasileiro para imigrantes internacionais, segundo regiões, continentes e nacionalidades ${ }^{10}, 2011,2014$ e 2017}

\begin{tabular}{l|c|c|c|c}
\hline \multirow{2}{*}{ Nacionalidade } & \multicolumn{2}{|c|}{ Vínculos ativos imigrantes internacionais } & $\begin{array}{c}\text { Taxa geométrica de } \\
\text { crescimento dos } \\
\text { vínculos (em \% a.a.) } \\
\text { entre 2011 e 2017 }\end{array}$ \\
\cline { 2 - 5 } & $\mathbf{2 0 1 1}$ & $\mathbf{2 0 1 4}$ & $\mathbf{2 0 1 7}$ & $\mathbf{3 1 , 3 5}$ \\
\hline Angolana & 366 & 626 & 1.880 & 56,82 \\
\hline Congolesa & 40 & 225 & 595 &.. \\
\hline Ganesa &.. & 148 & 312 &.. \\
\hline Senegalesa &.. & 207 & 718 & 10,47 \\
\hline Sul-Africana & 263 & 502 & 478 & 40,80 \\
\hline Outras Africanas & 501 & 3.390 & 3.904 & $\mathbf{3 7 , 4 4}$ \\
\hline \multicolumn{1}{c}{ Total África } & $\mathbf{1 . 1 7 0}$ & $\mathbf{5 . 0 9 8}$ & $\mathbf{7 . 8 8 7}$ & 10,84 \\
\hline Outras nacionalidades & 63.541 & 114.214 & 117.803 & $\mathbf{1 1 , 7 0}$ \\
\hline Total de vínculos & $\mathbf{6 4 . 7 1 1}$ & $\mathbf{1 1 9 . 3 1 2}$ & $\mathbf{1 2 5 . 6 9 0}$ & \\
\hline
\end{tabular}

Fonte: Relação Anual de Informações Sociais, Ministério do Trabalho e Previdência Social (RAIS-MTPS), 2011, 2014 e 2017. Tabulações Observatório das Migrações em São Paulo-NEPO/UNICAMP-Fapesp/CNPq.

9 Os dados referentes às diferentes nacionalidades do continente africano estão discriminados na base de dados da Relação Anual de Informações Sociais (RAIS) apenas para o período 20112017 e permitem a desagregação para imigrantes angolanos, congoleses, sul-africanos, ganeses e outros africanos. No entanto, entende-se que trabalhadores africanos já se encontravam presentes no mercado de trabalho formal brasileiro antes desse período ainda que o registro administrativo utilizado não apresente essa informação ao contabilizá-los no grupo "outras nacionalidades" para os anos que anteriores a 2011.

10 São apresentadas todas as nacionalidades discriminadas na Relação Anual de Informações Sociais do Ministério do Trabalho. 
O Gráfico 5 reforça o processo de mudança na distribuição espacial dos africanos no Brasil, entre 2011 e $2017^{11}$. Nota-se, no geral, uma crescente participação da região sul, especialmente no período de 2013 a 2016, acompanhada de perto pela região sudeste, que, apesar de ser o centro mais expressivo no início do período, perde espaço para o sul entre 2013 e 2016, retomando, minimamente sua participação no patamar de 2,7\% dos vínculos ativos de trabalho para esse grupo em 2017.

\section{Gráfico 5 - Participação dos vínculos de trabalho ativos em 31/12 no mercado formal para imigrantes internacionais africanos no total de vínculos para imigrantes, segundo Região, Brasil, 2011-2017}

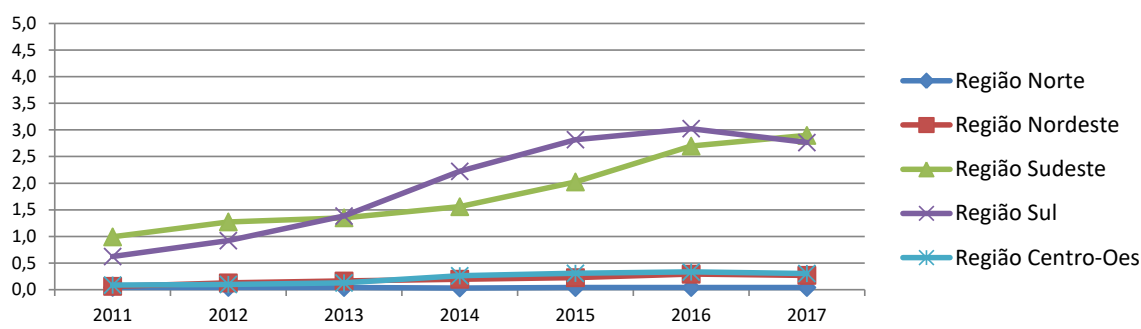

Fonte: Relação Anual de Informações Sociais, Ministério do Trabalho e Previdência Social (RAIS-MTPS), 2011-2017. Tabulações Observatório das Migrações em São Paulo-NEPO/UNICAMP-Fapesp/CNPq.

Além disso, é possível avaliar ainda três elementos fundamentais à compreensão dos fluxos migratórios de imigrantes africanos para o Brasil no século XXI: seu nível de instrução, renda média e os principais setores de inserção ocupacional desses profissionais. O Gráfico 6 discrimina os vínculos ativos de imigrantes africanos, respectivamente em 2011 e 2017, segundo nível de instrução nas diferentes regiões do país. Observa-se que, inicialmente há uma importante participação de imigrantes com o ensino fundamental incompleto, ensino médio completo e, especialmente na região sul, de profissionais com o ensino superior completo.

Em 2017 já há, comparativamente, uma mudança na composição geral das características apresentadas pelos profissionais africanos. Nota-se um crescimento dos registros de fundamental completo, ensino médio completo e de profissionais com superior completo (consideradas as diferentes escalas apresentadas). Destaca-se, assim, a diversidade de níveis de instrução observados nas regiões sudeste e sul do país no que tange a inserção laboral de imigrantes angolanos, congoleses, senegaleses entre outros.

\footnotetext{
11 Anos para os quais se tem a nacionalidade de imigrantes africanos discriminada.
} 


\section{Gráfico 6 - Vínculos de trabalho ativos em 31/12 no mercado formal para imigrantes internacionais africanos, segundo região e nível de instrução, Brasil, 2011 e 2017}

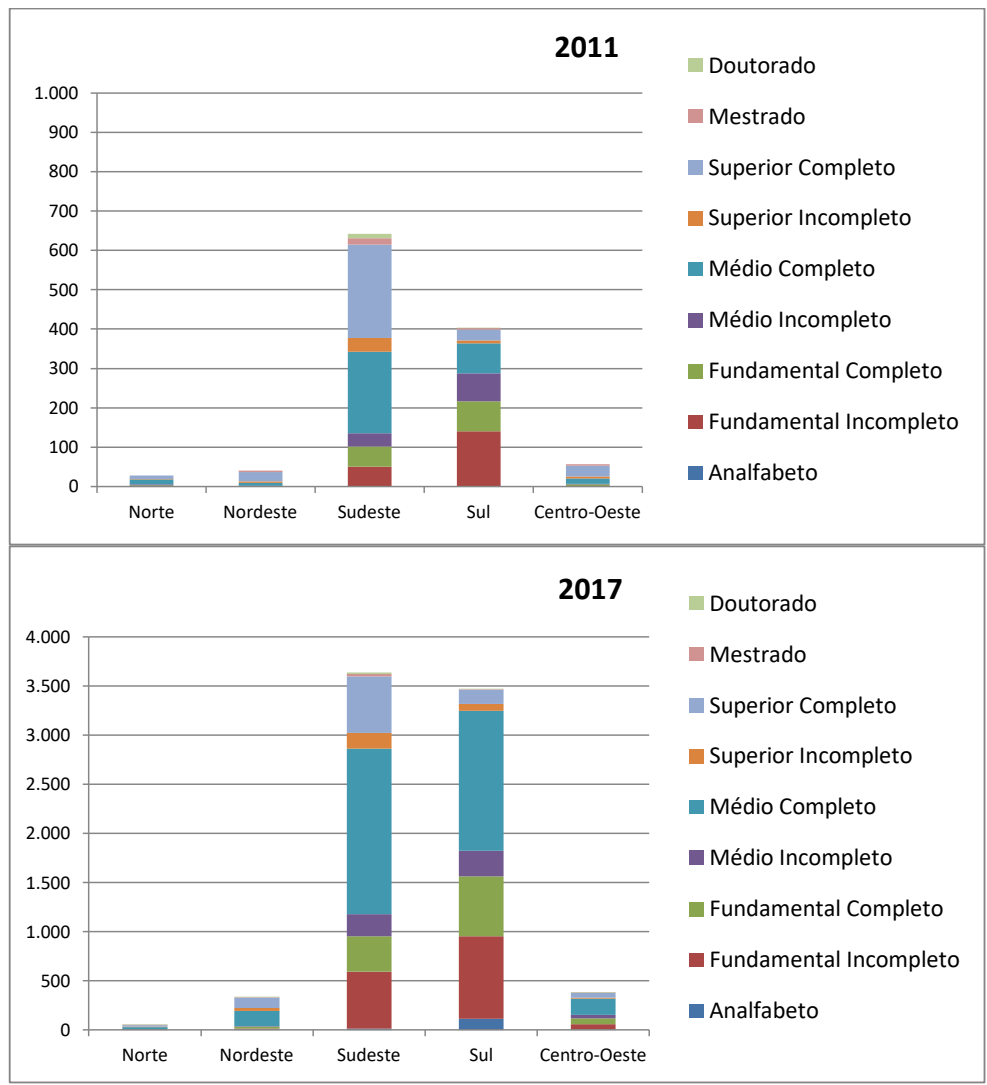

Fonte: Relação Anual de Informações Sociais, Ministério do Trabalho e Previdência Social (RAIS-MTPS), 2011-2017. Tabulações Observatório das Migrações em São Paulo-NEPO/UNICAMP-Fapesp/CNPq.

O Gráfico 7, por fim, apresenta a distribuição dos vínculos ativos de imigrantes africanos, em 2011 e 2017, de acordo com as regiões do país e os grupos ocupacionais discriminados. É fundamental considerar que se tratam de proporções estabelecidas a partir do volume de registros no mercado formal de trabalhadores africanos observados para cada região (Gráfico 6).

Assim, inicialmente, há uma participação relativa importante dos vínculos ativos de trabalhadores da produção de bens e serviços industriais I (trabalhadores que lidam mais com a forma do produto do que com o seu conteúdo físico-químico, "artesãos"), nas regiões norte (mais de $45 \%$ do total de registros), sudeste, sul e centro-oeste. São expressivos em 2011, também, os vínculos de trabalho para profissionais das ciências e das artes, sobretudo, no nordeste, centro-oeste, sudeste e norte do país. Ademais há que e avaliar 
que, em 2011, mais de 50\% dos registros de trabalho ativos diziam respeito aos trabalhadores da produção de bens e serviços industriais II. (trabalhadores de sistemas de produção que são ou tendem a ser contínuos: química, siderurgia, dentre outros).

\section{Gráfico 7 - Vínculos de trabalho ativos em 31/12 no mercado formal para imigrantes internacionais africanos, segundo região e grandes grupos ocupacionais, Brasil, 2011 e 2017}

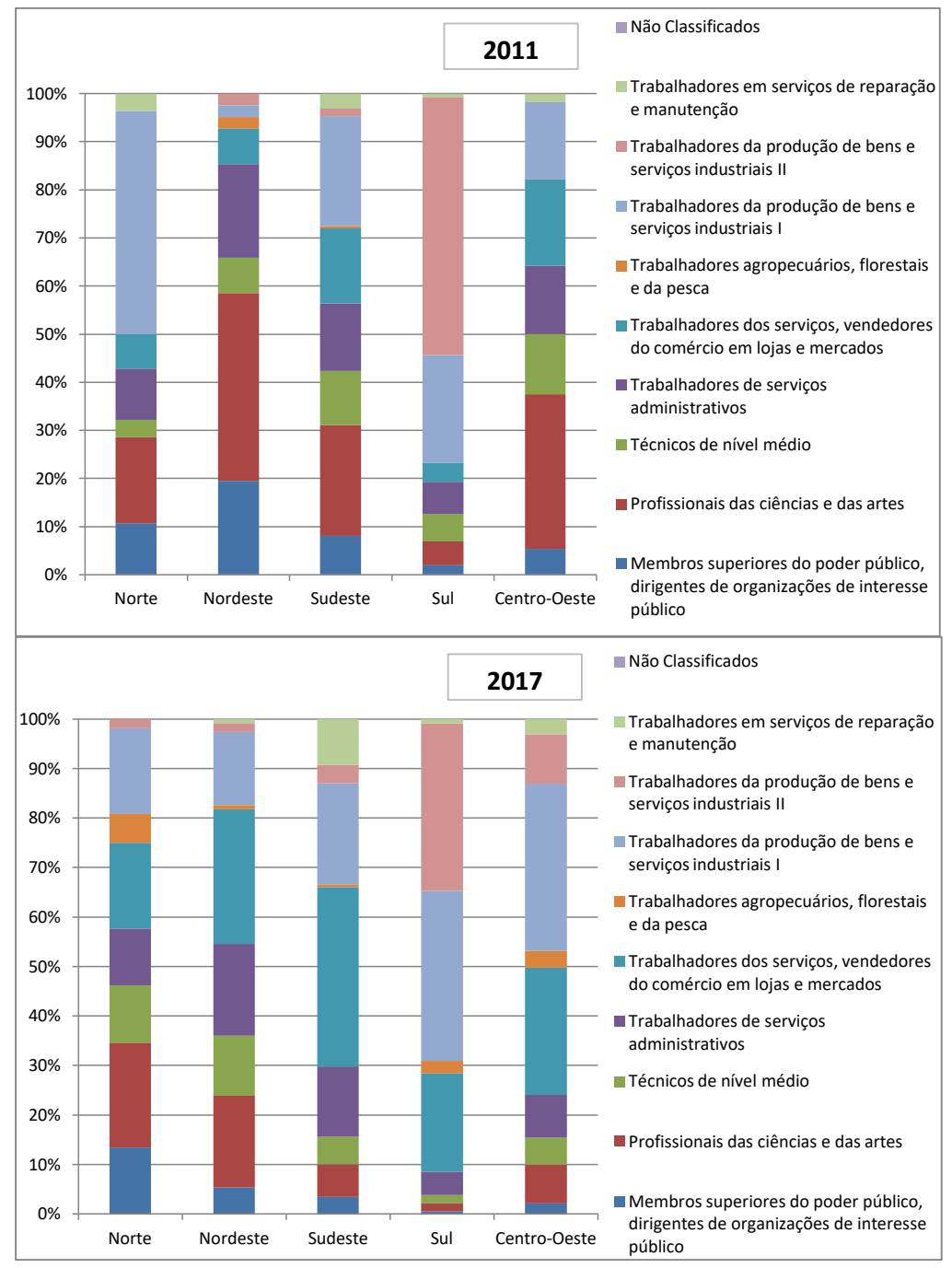

Fonte: Relação Anual de Informações Sociais, Ministério do Trabalho e Previdência Social (RAIS-MTPS), 2011-2017. Tabulações Observatório das Migrações em São Paulo-NEPO/UNICAMP-Fapesp/CNPq. 
Já para 2017 é possível observar uma maior diversificação na inserção laboral dos imigrantes africanos nos diferentes grupos ocupacionais considerados para todas as regiões do país (Gráfico 7). Cresce relativamente a participação dos vínculos ativos para trabalhadores agropecuários, florestais e da pesca na região norte e centro-oeste, bem como, de trabalhadores dos serviços, vendedores do comércio em lojas e mercados para todas as regiões do país. Nas regiões nordeste e sudeste, perdem espaço relativo - e em menor medida absoluto - os profissionais das ciências e das artes e membros superiores do poder público, dirigentes de organizações de interesse público. Por outro lado, ganham os trabalhadores em serviços de reparação e manutenção, o que seria indicativo de uma piora nas condições de inserção laboral desses imigrantes, visto que, a maior parte das ocupações relacionadas ao trabalho altamente qualificado, ou seja, à pesquisa, ciência e tecnologia encontra-se nos grupos com maiores perdas.

Sobre a renda média apresentada pelos imigrantes internacionais africanos, o Gráfico 8 apresenta dados para 2011 e 2017, segundo regiões administrativas e salário mínimo médio no ano.

De maneira geral, em 2011, ainda que predominassem os vínculos de trabalho de 1,01 a 3,00 salários mínimos, era possível observar uma participação de quase $40 \%$ para outros níveis salariais mais elevados, especialmente, nas regiões nordeste e sudeste.Em 2017, porém, os vínculos ativos de trabalho para imigrantes africanos no grupo "de 1,01 a 3,00 salários mínimos" passam a representar mais de $80 \%$ dos registros nas regiões centro-oeste, sul e sudeste. Uma participação absoluta muito superior tendo, em vista o crescimento na inserção laboral desses imigrantes no mercado formal entre 2011 e 2017.

\section{Gráfico 8 - Vínculos de trabalho ativos em 31/12 no mercado formal para imigrantes internacionais africanos, segundo região e Salário Mínimo (SM) médio, Brasil, 2011 e 2017}

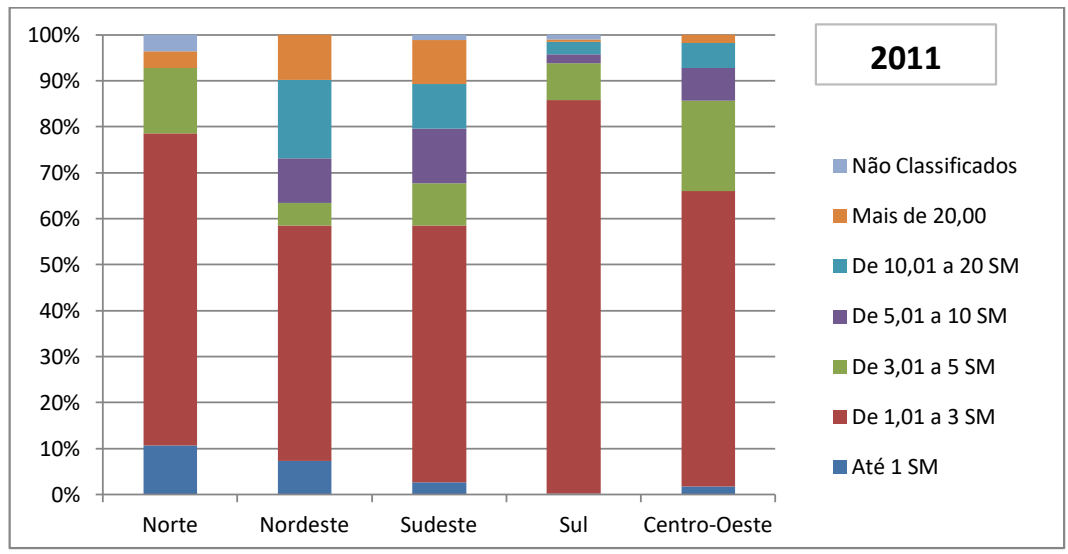




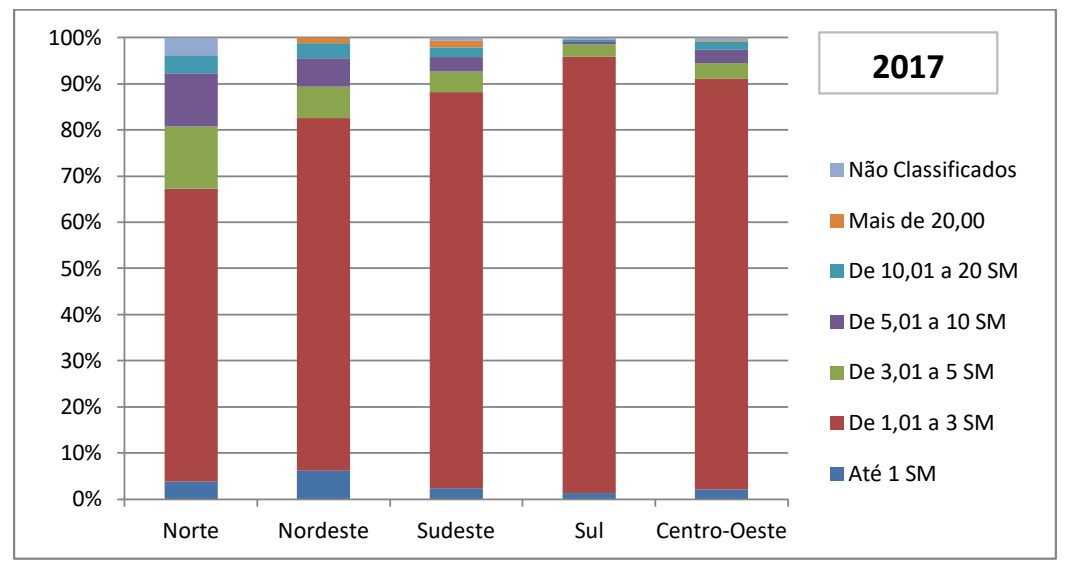

Fonte: Relação Anual de Informações Sociais, Ministério do Trabalho e Previdência Social (RAIS-MTPS), 2011-2017. Tabulações Observatório das Migrações em São Paulo-NEPO/UNICAMP-Fapesp/CNPq.

\section{Considerações Finais}

Tendo em vista a presença cada vez mais significativa de imigrantes africanos no Brasil, o artigo procurou apreender as especificidades e heterogeneidades desse fluxo migratório, composto por múltiplas modalidades migratórias (Wenden, 2001) que se estabelecem a partir da reprodução social dos imigrantes nos espaços da migração Sul-Sul (Baeninger, 2018). Esse fenômeno articula tanto transformações advindas da divisão internacional do trabalho, como processos que ocorrem dentro e no limiar das fronteiras nacionais (Baeninger, 2014; 2018; De Haas, 2010; Guarnizo et alii, 2003; Glick-Schiller, 2007).

Em nível global, a consolidação do Brasil como principal exportador de commodities do mundo, a aceleração de seu crescimento econômico entre 2002 e 2014 e as mudanças de sua política externa para o Sul Global (Manrique, 2012; Visentini, 2010) multiplicaram as conexões e os laços entre o país e continente africano, fortalecendo a constituição de um espaço transnacional de intensa circulação de pessoas, capital, bens e serviços (Sassen, 2010). Em paralelo, as maiores restrições à entrada de imigrantes nos países do Norte Global também fomentaram as migrações Sul-Sul (Phelps, 2016).

Em nível nacional, questões como a ampliação do acesso à documentação (Fernandes et alii, 2014), o fortalecimento da migração como direito humano (Assis, 2018; Mármora, 2010), as raízes históricas e as redes de migrantes existentes (Truzzi, 2008) também interferiram na inserção do Brasil na rota das migrações transnacionais e nos espaços destas novas imigrações.

Desde essa perspectiva teórica, o artigo analisa a imigração de africanos para o Brasil no âmbito das migrações Sul-Sul (Baeninger et alii, 2018; Phelps, 2016) e de modalidades migratórias (Wenden, 2001) de forma a compreender explicações que ultrapassem as fronteiras explicativas do Estado-nação (Glick- 
Schiller, 2007). Dentre as principais tendências verificadas destacam-se as transformações na distribuição espacial desses imigrantes, a inserção da fronteira Norte e das Regiões Sudeste e Sul como espaços da migração africana no país, assim como, a importância de refugiados e solicitantes, trabalhadores, estudantes, acadêmicos, missionários.

Em meio a esse processo, observou-se uma crescente presença de imigrantes africanos com ensino superior e médio completos no setor laboral de serviços brasileiro com rendimentos de até 3 salários mínimos, indicando a inserção laboral desigual de imigrantes africanos no país. Verificaram-se ainda mudanças na composição dessa população de imigrantes africanos por idade e sexo, com participação crescente de crianças, o que remete aos efeitos da reunificação familiar.

No conjunto, os registros administrativos da Polícia Federal, do Comitê Nacional para Refugiados e do Ministério do Trabalho corroboram o acompanhamento das mudanças na dinâmica migratória de imigrantes de diferentes países do continente africano como Angola, Guiné Bissau, Cabo Verde, Senegal, República Democrática do Congo, Gana, África do Sul, entre outros, para o Brasil, o que reforça a inserção do país na rota da migração transnacional africana no século XXI.

Os dados organizados nesse artigo abrem, portanto, uma agenda de pesquisa e destacam questões fundamentais à compreensão das dinâmicas migratórias contemporâneas e das práticas transnacionais (De Haas, 2010) estabelecidas pelos imigrantes que conectam, cada vez mais, demandas locais a processos globais (Sassen, 2010). Estas práticas se referem tanto aos lugares que se conectam na origem e no destino (como a entrada pela fronteira) quanto a circulação internacional e inserção laboral dos imigrantes (Domeniconi, Baeninger, 2016), compondo um movimento de trânsito migratório no Brasil. Somam-se a esses processos as dinâmicas familiares que se reconstituem em diferentes espaços da migração (Santos, 2018); a reconfiguração de práticas sociais e da atuação civil (Mármora, 2010); as múltiplas temporalidades e composições das práticas de uso de espaços e de lugares como recurso na estratégia da migração transnacional (Baeninger, 2018), entre outras.

Esse cenário migratório da África para o Brasil, portanto, passa a se constituir em um espaço transnacional da migração internacional e de reprodução social (Canales, 2015) que conecta origens e destinos das migrações contemporâneas (Baeninger, 2018) reconfigurando fluxos históricos no século XXI.

\section{Referências Bibliográficas}

ASSIS, Glaucia de Oliveira. Nova Lei de Migração no Brasil: Avanços e Desafios. In: BAENINGER, Rosana et alii. Migrações Sul-Sul. 2a edição. Campinas, SP: Nepo/ Unicamp, 2018. 
BAENINGER, Rosana. Migrações transnacionais na fronteira: novos espaços da migração Sul-Sul. In: BAENINGER, Rosana; CANALES, Alejandro (coords.). Migrações fronteiriças. Campinas, SP: Nepo/Unicamp, 2018.

BAENINGER, Rosana. Migrações transnacionais de refúgio no Brasil. In: LUSSI, Carmem (org.). Migrações internacionais: abordagens de direitos humanos. Brasília, DF: Centro Scalabriniano de Estudos Migratórios, 2017.

BAENINGER, Rosana. Migrações Internacionais no século 21: desafios para uma agenda de pesquisa. Trabajo presentado en el VI Congreso de la Asociación Latinoamericana de Población, realizado em Lima-Perú, del 12 al 15 de agosto de 2014.

BAENINGER, Rosana et alii. Migrações Sul-Sul. 2ª edição. Campinas, SP: Nepo/ Unicamp, 2018.

BAENINGER, Rosana et alii. Atlas temático: Observatório das Migrações em São Paulo - Migrações internacionais. Campinas, SP: Nepo/Unicamp, 2017.

BAENINGER, Rosana et alii. Imigração Haitiana no Brasil. Jundiaí, SP: Paco Editorial, 2016.

BAENINGER, Rosana; PERES, Roberta G. Migração de Crise: a migração haitiana para o Brasil. Revista Brasileira de estudos de População, v. 34, p. 119-143, 2017.

BAENINGER, Rosana; SILVA, João Carlos Jarochinski. Migrações Venezuelanas. Campinas, SP: Nepo/Unicamp, 2018.

BRASIL. Refúgio - Perguntas Frequentes. Brasil: Ministério da Justiça e Segurança Pública - Governo Federal, Brasília/DF. Disponível em: <https://www.justica. gov.br/seus-direitos/refugio/perguntas-frequentes\# processodereconhecimentod acondicaoderefugiado $>$. Acesso em: 01.06.2019.

BREDOW, Sabrina M. S.; LÉLIS, Marcos T. C.; CUNHA, André M. O ciclo de alta nos preços das commodities e a economia brasileira: uma análise dos mecanismos externos de transmissão entre 2002 e 2014. Economia e Sociedade, Campinas, v. 25, n. 3 (58), p. 695-731, dez. 2016.

CANALES, Alejandro. E pur si Muove. Elementos para una teoría de las migraciones en el capitalismo global. México: Universidad de Guadalajara y Miguel Ángel Porrúa, 2015.

DE HAAS, Hein. Migration and development: a theoretical perspective. International Migration Review, v. 44, n. 1, p. 227-264, 2010.

DOMENICONI, Jóice; BAENINGER, Rosana. Trabalhadores do Conhecimento na imigração internacional: o caso de São Paulo. In: Anais do VII Congresso da Associação Latino-americana de População e XX Encontro Nacional de Estudos Populacionais, Foz do Iguaçu/PR - Brasil, 2016.

DOMENICONI, Jóice; BAENINGER, Rosana; DEMÉTRIO, Natália. Migrações transnacionais da África para o Brasil: perfil sociodemográfico no século XXI. Anais do XIII Congresso Luso-Afro-Brasileiro de Ciências Sociais e $2^{\circ}$ Congresso da Associação Internacional de Ciências Sociais e Humanas de Língua Portuguesa, Guarulhos/SP - Brasil, 2018. 
DOMINGUEZ, Juliana A.; BAENINGER, Rosana. Programa de Reassentamento de Refugiados no Brasil. In: XV Encontro Nacional de Estudos Populacionais, 2006, Caxambú. Anais... Caxambú- MG: ABEP, 2006.

FERNANDES, Duval et alii. Estudos sobre a migração haitiana ao Brasil e Diálogo Bilateral. Relatório Ministério do Trabalho/OIM/PUCMinas, 2014.

GLICK-SCHILLER, Nina. Beyond the Nation-State and Its Units of Analysis: Towards a New Research Agenda for Migration Studies - Essentials of Migration Theory. Center on Migration, Citizenship and Development, Arbeitspapiere - Working Papers, n. 33, 2007.

GUARNIZO, Luis; PORTES, Alejandro; HALLER, William. Assimilation and Transnationalism: Determinants of Transnational Political Action among Contemporary Migrants. American Journal of Sociology, v. 108, n. 6, p. 1211-1248, 2003.

GUSMÃO, Neusa Maria Mendes de. Africanos no Brasil, hoje: imigrantes, refugiados e estudantes. Tomo (UFS), v. 21, p. 13-36, 2012.

HAGE, Fabio A. Santana; PEIXOTO, Marcus; VIEIRA FILHO, José E. Ribeiro. Aquisição de Terras por Estrangeiros no Brasil: uma Avaliação Jurídica e Econômica. Texto para Discussão. Brasília/Rio de Janeiro: Instituto de Pesquisa Econômica Aplicada, novembro de 2012.

HARVEY, David. Condição pós-moderna: uma pesquisa sobre as origens da mudança cultural. São Paulo: Edições Loyola, 1992.

MANRIQUE, Luis Esteban. El emergente eje 'Sur-Sur' global. Política Exterior, n. 146, marzo/abril de 2012.

MÁRMORA, Lelio. Modelos de Gobernabilidad Migratoria. La perspectiva política en América del Sur. REMHU, Revista Interdisciplinar da Mobilidade Humana, Brasília, v. 18, n. 35, p. 71-92, jul./dez. 2010.

PHELPS, Erin. D. South-South Migration: Why it's bigger than we think, and why we should care. The Migrationist, 2014.

SANTOS, Milton. Técnica, espaço, tempo. 5aa ed. São Paulo: Editora da Universidade de São Paulo, 2013.

SANTOS, Sandro Martins de Almeida De Cuba ao Brasil: alternativas transfronteiriças de reunião familiar. In: BAENINGER, Rosana; CANALES, Alejandro (coords.). Migrações fronteiriças. Campinas, SP: Nepo/Unicamp, 2018, p. 359-367.

SASSEN, Saskia. As cidades na economia mundial. São Paulo: Studio Nobel, 1998. SASSEN, Saskia. Sociologia da Globalização. Porto Alegre: Editora Artmed, 2010.

SILVA, João Carlos Jarochinski. Migração forçada de venezuelanos pela fronteira norte do Brasil. Anais 41 Encontro Anual da ANPOCS, Caxambu/MG-Brasil, 2017.

TRUZZI, Oswaldo M. S. Redes em processos migratórios. Tempo Social, v. 20, p. 199-218, 2008.

VISENTINI, Paulo G. F. Cooperação Sul-Sul, Diplomacia de Prestígio ou Imperialismo 'soft'? As relações Brasil-África do Governo Lula. Século XXI - Revista de Relações Internacionais, v. 1, p. 65-84, 2010.

WENDEN, Catherine Wihtol de. Un essai de typologie des nouvelles mobilités. Hommes \& migration, n. 1233, p. 5-12, 2001. 